\title{
Bestsellers beyond Bestsellers: The Success of a Good Story
}

\section{Michael Wright Johnson, Circulation Librarian, USA}

\begin{abstract}
This article examines the recent trend of books and book series gaining popularity with unprecedented speed. By closely examining the release and success of The Da Vinci Code and the Harry Potter series, early publications that experienced this trend, certain factors were discovered. The author points out some strong similarities between the titles and how developments in international marketing have contributed this change in publishing. Factors contributing to success include speedy production of excellent translations, modern marketing, similar story trends and similar character reader interaction. The similarities are repeated in more recent books that have followed this trend of quick international popularity.
\end{abstract}

Keywords: Publishing, Marketing, Harry Potter, Da Vinci Code, Books, Print 


\section{Introduction}

Modern publishing houses are always seeking the next popular fiction best seller. Textbooks and instruction manuals have always sold well and have been a safe backbone for the publishing industry for decades. At the same time there is always a potential for massive profits from a successful popular fiction novel or series of novels. This potential profit can come at great risk with the possibility ofpromoting a book that does not become bestseller or only identifying fiction book after word of mouth makes it successful, which can hurt sales. Waiting too long to grab a potential bestseller couldallow the title to be published by a competitor.

In the last two decades a new type of bestseller has emerged that has sold in quantities much greater than previous bestsellers. An interesting difference about these books is the fact that they have crossed cultures and languages that have had very little in common with the original intended audience. They have spread like a virus, and it is hard to go anywhere in the world where these books have not known and at least some people have read them, either in translation or in English. Two early examples of these kinds of books are The Da Vinci Code and the Harry Potter series. Both of these titles exploded throughout the world very quickly, spinning off moviesalong with collectibles and toys that are sold in ordinaryshops and even as high end products in SkyMall (www.skymall.com).

There are many theories about why these books have been so successful. Some think it due toaggressive marketing, others with the quality of the translation and some because of the appealing story. It is easy to imagine a pyramid, with the story as the base and the side supports as marketing and translation. This theory could not be further from the truth. The pyramid implies a codependence of all three sides to make a book an international bestseller. Even if a bad book, one that is not a market success, is given great marketing and a superior translation these advantages still will not make itmuch more successful.This theory even applies to bad books written by authors known for producing bestsellers (Greco A, Rodriguez C, Wharton R, 2007).

A good book, one that has market success, can grow in popularity without aggressive marketing and even a bad translation can be redone. The book's popularity will just grow much slower. If a good book receives aggressive marketing and good translations it can 
become a worldwide bestseller quickly. Without the starting point of a good story, The $\mathrm{Da}$ Vinci Code and the Harry Potter books would have never been as successful as they were no matter how aggressive the marketing or how good the translation.

\section{What Makes These Books Different}

There have always been best sellers since the beginning of the book industry starting with the era of the hand press (Steinberg S, 2005). In the modern era major commercial publishing houses have to depend on bestsellers for the majority of their profit (Greco A, Rodriguez C, Wharton R, 2007). Research has shown 7 out of 10 frontlist books actually lose money, 2 out of 10 break even and only 1 book in 10is that big hit that covers the cost of the loses of the rest (Greco A, Rodriguez C, Wharton R, 2007 p 30).

If big bestsellers are nothing new what makes The Da Vinci Code and Harry Potter so important? The answer is the number of copies sold and how quickly they spread. The $D a$ Vinci Code had sold over 25 million copies in 44 languages before it was even released in paperback (Drummond K, 2006 p 65). The Da Vinci Code held number 1 on thebestseller list for 2 years, and as of 2008 there were over 70 million copies of the book in circulation around the globe (Adams L, Heath J, 2007 p 261) (Gunelius S, 2008 p 136). The amount of revenue generated by The Da Vinci Code does not end there. A large number of spin off books or books related to the artwork mentioned in the book have also became become best sellers, including books debunking or critiquing the accuracy of The Da Vinci Code (Drummond K, 2006). These books have generated untold wealth for the publishing companies and booksellers.

Another effect ofThe Da Vinci Code is theunknown number of people who were inspired by it to travel to the places mentioned in the book. It is possible to arrange specialty tours, which explain the different aspects of the books in the actual places (Cosgrove-Mather B, 2004). When all of the direct and indirect revenue created by this book is considered it must be quite remarkable.

The overall success of the Harry Potter books is similar. As of 2008 the Harry Potter series has sold over 400 million copies worldwide and had been translated into 67 languages (Dammann G, 2008). When Harry Potter and The Order of The Phoenixwas released, 
Borders, Barnes \& Noble and Walmart combined sold more than 1,966,000 copies in the first week ("Phoenix sales remain strong" Publishers Weekly, 2003 p 10). The global sales for Harry Potter and The Order of The Phoenix on the first day alone are estimated at 6.8 million (Gunelius S, 2008 p 76). This peaked with Harry Potter and the Deathly Hallows at 11 million sales on the first day (Gunelius S, 2008 p 76).

Joanne Rowling, who wrote her first novelas a single mother on welfare, is now worth over 1 billion dollars (Forbes, 2010). The overall revenue generated from the Harry Potter brand is not just limited to book sales. The first 6 Harry Potterfilms have grossed an astounding 5 billion dollars internationally (Forbes, 2010). This does not include the 6 billion dollars that Warner Brothers has made in retail globally (Lisanti T, 2009 p 67). In the USA consumers see Harry Potter products everywhere but the affect is global. When I was living in a suburb of Shanghai in 2007 a new shopping mall opened and one of the shops only sold licensed high-end Harry Pottermerchandise including Hogwarts robes for men and women. These numbers do not include the number of illegal or spin off wizard products, which range from bootleg copies of books and DVDs to artists selling homemade wands on Etsy.com (http://www.etsy.com/shop/mmwalter, accessed on April 21,2010).

All of this commercial activityis due toseven books. However, much of this total wealth also comes from royalties derived from movies and other products. But, those other sources of revenue would not exist if it were not for the seven books. The same can be said of The Da Vinci Code, without that first book none of this revenue would have been generated.

The Harry Potter series of books is only topped by two other works in terms of number published. The Quotations of Chairman Maohas a worldwide circulation of 800 million copies and The Bible has a circulation of 2.5 billion copies since 1815 (Brown S, 2005 online accessed April 12, 2010). The key difference among these books is that the success of Harry Potter and the The Da Vinci Code was market driven. People who bought these books for their personal entertainment determined the massive numbers published.

Various churches and religious organizations subsidized the majority of bibles that have been published while the propaganda machine of China published The Quotations of Mao for political reasonsnot to make a profit. Another example is that until the fall of the Soviet Union, Lenin had regularly topped the lists of the most translated authors of all time 
(Naravane V, 1999/2000). Once the Communist regime fell the writings of Lenin lost their financial underwriting because the new governments of the former Soviet Union no longer supported the propaganda. No publishing company was going to publish the writings of Lenin at a financial loss.

\section{Translations}

Part of the cost of publishing these titles was the cost of high quality translations in numerous languages. Since The Da Vinci Code and the Harry Potter books were very popular in the English language market good translations were made in many languages. The high cost of these translations was offset by their market success.

Books have always been translated. Socrates and Aristotle did not write their works in Latin, they were written in ancient Greek. Then these works were translated into countless languages over the centuries, most of which did not even exist when the works were first written. After the invention of the printing press popular works were quickly translated and published across Europe. Even at that time it was known that a high-qualitytranslation of a good book always sold better than a poor translation. A modern day example is the classic,Alice in Wonderland. It was a very successful book globally,but it did not become popular in Germany untilthe 1970s because of a new translation (Lathey G, 2005). The early poor translation ofAlice in Wonderland, determined its initiallack of market success in Germany.

Translation from the original language to a different language takes time. From the hand press period to the modern era this period was usually several years. Classics like Cinderella and Winnie-the-Pooh took several years to go from original text to translation to market success. Part of selling a book is the buzz it creates and the information cascade created by a popular reception (Greco A, Rodriguez C, Wharton R, 2007). An information cascade is different sources, such as television shows, blogs, radio programs, reviews and word of mouth that positively mention aproduct.

In the modern global economy this buzz needs to be done on an international scale for products intended for a wide audience. The time frame from the original printing of Harry Potter and the Philosopher's Stone in English to its Chinese translation was almost three 
years (Lathey G, 2005). While for Harry Potter and the Order of the Phoenix this delay from English to Chinese was only 3 months, Spanish 6 months and Japanese 1 year ("Potter craze" Publishers Weekly, $2003 \mathrm{p} \mathrm{10).} \mathrm{These} \mathrm{rapid} \mathrm{translations} \mathrm{demonstrate} \mathrm{how} \mathrm{the}$ information cascade is a global phenomenon. Although good and quick translations help with the information cascade it is not the sole reason for producing quick translations for the Harry Potter books and The Da Vinci Code.

There is a direct market impact if good translations are not made and published quickly. It is easier to buy English versions in different countries now than it was in the past from Internet vendors like Amazon.com ("Potter craze" Publishers Weekly, 2003 p 10). Local publishing companies that buy the translations rights need to publish translations more quickly in order to prevent being undercut by the English version. This problem is also compounded by the fact that even today with modern language education it is difficult to find good professional translators (Lathey G, 2005).

Arecent problem for authors and publishersis"fan"written and other unofficial translations of major booksthat are posted on the Internet or even printed. Not only can some of these be inaccurate or poorly done they provide no royalties to thepublishing company that owns the translations rights ("Fake Harry Potter novel hits China" BBC News World Edition, 2002). With these direct and illegal competitors publishing companies that have purchasedthe translation rights want as quickly as possible to translate the books and get them on bookstore shelves (French H, 2007). Otherwise there will be bootleg editions sold on blankets in front of the bookstore on the streets of Shanghai (French H, 2002). The drive to create so many pirate editions of these books is a result of the success of the marketing and quality of the original book.

\section{Marketing}

Marketing has always been part of the commercial book trade. The reason why the first printed book by Guttenberg was a bible was because there was a market at the time for bibles. Marketing has changed greatly since the time period of the first hand press book, however the goal has always been the same, sell more copies and sell them more quickly (Greco A, Rodriguez C, Wharton R, 2007). If a book receives absolutely no marketing it will most 
likelyfail no matter how good the book is. At the same time even if a bad book receives aggressive marketing it will not improve the sales (Greco A, Rodriguez C, Wharton R, 2007).

In the last few decades many people in marketinghave tried to make their field more scientific,including using complex formulas and intensive research (Brown S, 2005). According to most research there is no magic formula for making a book a success. If anything a book'spopularity is random, and it is hard to predict what will be a major success no matter which scientific analysis is used (Greco A, Rodriguez C, Wharton R, 2007).

The decision to publish The Da Vinci Code is a perfect example. When the book first arrived on the desk of the editor he crunched the numbers and looked at the market research, and according to that data the book should be a moderate success (Drummond K, 2006). This data was based on the fact that Dan Brown was an unknown author; the book would not come out in time for the Christmas season; and it was not sexy enough for a beach book. There was one factor outside of the data that influenced the decision. The editor stayed up all night reading the book and could not put it down.

Other editors and the fiction buyer for Barnes \& Noble had the same reaction. They could not stop reading the book. The original editor and the president of Double Day decided to take the risk and to aggressively market this book only because a few people have read it and finished extremely quickly. This massive marketing campaign, mainly decided by personal reactions, was a major success. If anything the data suggested by the scientific marketing analysis was wrong.

The marketing of the Harry Potter books is a slightly different story. The marketing exploits of the later books have been well publicized including themidnight opening of sales at bookstores across the world, books in cages for a week before they are sold and a steam train arriving at Kings Cross station (Lathey G, 2005). For the first book there was no marketing bonanza. When looking at the raw data a marketing expert would say the book is culturally British, takesplace in a traditional boarding school, features a boy as the main character, when most younger readers are female, and is too long (Tucker N, 1999). In addition, similar to Dan Brown, Joanne Rowling was a freshmen authorand completely unknown to the public. 
Maybe because of these factors Harry Potter and the Philosopher's Stone received a short run in its first edition. Most of these editions were sold directly to school and children's sections of libraries. Because of this small printing the first edition of Harry Potter and the Philosopher's Stone is a very expensive item. The first book initially grew in popularity because of word of mouth and then dramatically increased in sales as it appeared on the short list of several book awards.

For books, especially popular ones, consumption is marketing, meaning that as consumers read the books more people want to read them. (Drummond K, 2006). This causes more sales growth, which in turn causes even more sales of the book. As the Harry Potter books and The Da Vinci Code grew in popularity it caused more people to want to buy them. Six more books after the first one in the Harry Potter series would continue to grow in away that very few books have.

\section{The Good Story}

The importance of a good translation and successful marketing cannot be ignored when it comes to a book's success. However, as already stated,good marketing for a bad book may draw early sales but it cannot push that book to be a bestseller. The story must be attractive and appealing to consumers in order to get them to buy the book or borrow it from someone or a library. What elements of a good story doHarry Potter and The Da Vinci Code have in common? The formula to make a book a success is not a science and many books that have these elements fail. However there are several common aspects of these books that are quite interesting.

Some critics may say that the Harry Potterbooks and The Da Vinci code were lucky because of the times or external events in the world. I believe Nicholas Tucker says it best when writing about the success of Harry Potter, and this statement also can be applied to The Da Vinci Code:

"Rowling's Success, however, was never merely the result of good publicity. It also had nothing to do with government initiatives like the literacy hour or the specially designated Year of Reading. To an extent, her triumph is all her own..." (1999, p 232) 
The success of these books is the fact they are written in certain ways that give them mass appeal. The ability to write this way is something most writers cannot or will not do.

The first element is the inability of the reader to compete with the main characters (Tucker N, 1999). Readers are reading books for entertainment. The reader will not be entertained if the hero in the book makes them feel stupid about themselves or belittles themwith their actions in the story. In Harry Potter the inability to compete is very clear. Harry Potter and the other characters in the book excel in magic, something that does not exist in the real world. This means that readers can enjoy the success of Harry Potter and other characters without feeling that they would fail at that same activity. Certain characters who are known as the smart ones or super good students do not offend readers in the same way because their success is not possible in the reader's real life.

Applying this element to The Da Vinci Code is a little more difficult. The characters do not use magic or have some sort of special power. At the same time the main character, Robert Langdon, is very hard to compete with. He is a famous Harvard symbologist, which is not a real field of study. This fictitious job would not cause readers to feel competition. The few people in the world who might study anthropology and art history in this area would be a very small part of the market.

The second element is that the reader feels as if he is part of a secret (Tucker N, 1999). In Harry Potter it is being part of this secret wizard world. The reader is given a glimpse of this secret world, which exists alongside the normal world, and is allowed to participate. In most other fantasy genre books the entire world is a magical world such as books by J. R. R.Tolkien and George R. R. Martin.In the Harry Potter books the magical world is a subculture in our own worldthat normal people do not knows about. With The Da Vinci Code the secret is a hidden scandal dating back thousands of years affecting millions of people. The reader is allowed in on the secret and they feel that they are part of the world of high art and Catholic power (Drummond K, 2006).

The last element for a successful book is the reader's desire to feel that they fit in and belong with their group or friends(Drummond K, 2006). This ties directly into opinion leadership theory which has found that that opinion leaders, an active media user who is considered an 
expert, has more affect on what people purchase or consume then professional marketing (Elih K, 1956). If an opinion leader says a books is good and should be read people are more likely to read it. When multiple opinion leaders emphasize this point then non-opinion leaders in that area will want to read it more.

If a possible reader is with a group of people, either opinion leaders or normal consumer, who are talking about a bookthat the possible reader has not read, the possible readermay read it in order to feel that he is participatingin the conversation (Drummond K, 2006). For example I only starting reading the Harry Potter books because students pestered me about them for 5 years; I decided that I needed to read them in order to answer their questions andmystudents'ranged from young children to middle age adults. The question is-- how many people decided to read Harry Potter or The Da Vinci Code because they wanted to know what all the fuss was about or to be in the loop?

These elements exist in many books and it difficult to tell which book will be very popular and which will fail. As mentioned before,The Da Vinci Code's early research showed it would only have moderate success. The first Harry Potter book was rejected by at least two major agents (Tucker N, 1999). The only reason why the Christopher Little Agency decided to represent Joanne Rowling is because Christopher Little's secretary, Bryony Evens, read the sample chapters in a unique binding that caught Evens eye, and made her boss request the entire manuscript (Gunelius S, 2008). Even after an agent accepted the book, it took a year and was rejected by 12 publishers before one agreed to publish only 500 copies in the first run (Gunelius S, 2008 p 6). The first Harry Potter book only became very successful by word of mouth (Lathey G, 2005). Including the above elements in a book will not guarantee a big success but many writers are only able to write an enormously popular book once.

\section{Conclusion}

The general rule in marketing is that it can only effectively promote a product to the point of how good that product is (Gunelius S, 2008). The better the product, the easier the marketing will be because the book will sell itself. In the case of the Harry Potterbooks and The Da Vinci Code these products were so good that aggressive marketing could make them into super-hot products. 
Merchandising and film adaptations of these books have netted billions of dollars. The 8 Harry Potter films grossed $\$ 7.7$ billion globally (Pomerantz D, 2012) and The Da Vinci Codegrossed \$758 million (Gunelius S, 2008). In particular the plans to market the Harry Potter brand seem endless and some have equated it to the Star Wars brand, which has not died out since it started in the late 1970s (Gunelius S, 2008).

The trend of bestsellers beyond best sellers has only continued since The Da Vinci Code and the Harry Potter books were published. The Twilight books, as of 2009, sold over 70 million copies worldwide (Barnes, 2009). By 2012 the Hunger Games Trilogy sold over 50 million copies in the United States, 23 million for The Hunger Games, 14 million copies for Catching Fire, and 13 million copies for Mockingjay (Straaten T, 2012). And the most recent bestseller phenomenon, the Fifty Shades Trilogy, sold over 70 million copies globally between March and December of 2012(Sweney M, 2013). All of these newer books have been made into or currently being produced as major film franchises and have had world wide appeal similar to the Harry Potter books and The Da Vinci Code. All of this success is due to good books, with good stories but these books are alwayshard to spot and easy to miss. 


\section{References}

Adams, L. \& Heath, J. (2007). Why we read what we read. Naperville, IL: Sourcebooks INC

Barnes, B. (2009, Nov 19). Twlight: By the number. New York Times: ArtBeat retrieved from http://artsbeat.blogs.nytimes.com/2009/11/19/twilight-by-the-numbers/

BBC News: World Edition (2002, July 4). Fake Harry Potter novel hits China. Retrieved from: http://news.bbc.co.uk/2/hi/entertainment/2092661.stm

Brown, S. (July, 18 2005). Harry Potter brand wizard.Business Week retrieved from http://www.businessweek.com/innovate/content/jul2005/di20050721_060250.htm

Brown, S. (2005). Wizard! Harry Potter's brand magic. Cornwall: Cyan Books CosgroveMather, B. (September, 9, 2004). 'Da Vinci Code' spans travel fad. CBS News retrieved from http://www.cbsnews.com/stories/2004/09/09/world/main642450.shtml

Dammann, G. (June, 182008). Harry Potter breaks 400 million in sales. UK Guardian retrieved from http://www.guardian.co.uk/books/2008/jun/18/harrypotter.news

Drummond, K. (2006). Culture club. In Brown, S,Consuming books (60-72). New York, NY: Routledge

Elihu, K. (1956). The two-step flow of communication: An Up-to-date report on hypothesis. Public Opinion Quarterly, 21, 61-78

Etsy.com. Retrieved from http://www.etsy.com/shop/mmwalter, on April 21,2010

Forbes. (2010). The worlds billionaires. Retrieved from

http://www.forbes.com/lists/2010/10/billionaires-2010_Joanne-(JK)-

Rowling_CRTT.html

French, H. (2007, July, 31). What is the seventh Potter book called in China? The New York Times retrieved from http://www.nytimes.com/2007/08/01/world/asia/01iht01 china.6930312.html?pagewanted=all\&_r=0

Greco A., Rodriguez, C. \& Wharton, R. (2007).The culture and commerce of publishing in the $21^{\text {st }}$ century. Stanford, CA: Stanford Business Books

Gunelius, S. (2008). Harry Potter: The story of a global business phenomenon. New York, NY: Palgrave MacMillan

Lathey, G. (2005). The travels of Harry: International marketing and the translation of J.K. Rowling's Harry Potter books. The Lion and the Unicorn, 29(2005), 141-151

Lisanti, T. (2009).Warmer Bros. and the magic world of Harry Potter.License! Global, 12 (5), 66-74 
Naravane, V. (Winter 1999/2000). Fifty years of translation: The Index Translationum completes a half century. Publishing research quarterly, 15 (4), 23-38

Pomerantz, D. (December, 13, 2012) Can 'The Hobbit" make "Lord of the Rings' the top film franchise of all time? Forbes. Retrieved from: http://www.forbes.com/sites/dorothypomerantz/2012/12/13/can-the-hobbit-make-lordof-the-rings-the-top-franchise-ever/Publishers Weekly 250(27) pg 10 (July, 72003 ). 'Phoenix' sales remain strong in most channels.

Publishers Weekly 250(27) pg 10 (July, 7 2003). Potter craze has dark lining for foreign houses

Tucker, N. (1999). The rise and rise of Harry Potter.Children's Literature in Education, 30(4), 221-234

Sky Mall.Retrieved from www.skymall.com on April $20^{\text {th }} 2010$.

Steinberg, S.H. Five Hundred Years of Printing. New Edition, revised by John Trevitt (London: The British Library, and New Castle, Delaware: Oak Knoll Press, 1996) Straaten, T. (2012, July, 19). Scholastic Announces Updated U.S. Figures for Suzanne Collin's Bestselling The Hunger Games Trilogy. Retrieved Form: http://mediaroom.scholastic.com/press-release/scholastic-announces-updated-usfigures-suzanne-collinss-bestselling-hunger-games-tril

Sweney, M. (2013, March, 26). Fifty Shades of Grey publishing Random House posts record profits. The Guardian. Retrieved: http://www.theguardian.com/media/2013/mar/26/fifty-shades-random-house-recordprofit 